\title{
Implementation of Law Number 13 Year 2003 Concerning Labor Related to Legal Protection Against Outsourcing Workers in Ternate City
}

\author{
Rusli N. Tawary; Wahda Z. Imam; Suwarti \\ Universitas Khairun Ternate, Indonesia \\ http://dx.doi.org/10.18415/ijmmu.v8i9.2917
}

\begin{abstract}
This research is about legal protection for workers/laborers at outsourcing service companies in Ternate City related to the protection of the rights of outsourced workers/laborers in which workers' rights are normative rights in the form of permanent or contractual employment relationships, wages/salaries that are in accordance with the UMK, normal working hours, the rights of BPJS Employment and BPJS Health, protection at work using PPE personal protective equipment so that workers/laborers can be protected from the risk of occupational accidents, the company's obligation is to carry out all the fulfillment of workers'/labor's rights which have been regulated in the regulations employment. That legal protection for the people is a preventive and responsive government action. Preventive legal protection aims to prevent disputes from occurring, which directs government actions to be careful in making decisions based on discretion and responsive protection aims to prevent disputes from occurring, including their handling in the judiciary.
\end{abstract}

Keywords: Legal Protection, Rights of Outsourcing Workers; Obligations of Outsourcing Service Companies

\section{Introduction}

Observing the "company" as a symbol of the dominant economic system, it becomes inherently clear, its structure and function are the antithesis for the legal protection of workers/laborers, the two contradict each other, there is always a gap between das sollen (must) and das sain (reality) and there is always a discrepancy between law in the books and law in action. The presence of the State which was originally expected to provide guarantees for the protection of the basic rights of workers/ laborers, in fact the opposite happened, the presence of the State seemed more repressive and even exploitative to the interests of workers/ laborers. Meanwhile, the role of the state in industrial relations seems to be facilitative and accommodating to the interests of investors. Indications of weak legal protection for workers/labor can be seen from the problem of outsourcing (Alih Daya) which has recently become an actual national issue. The problem of outsourcing (Outsourcing) is indeed quite varied along with the acceleration of its use which is increasingly widespread in the business world, while the existing regulations are not sufficient to regulate outsourcing which has been running in the midst of economic life with the hegemony of financial capitalism that operates through "dis-solution subject", which do not view workers/labourers as production subjects who should be protected, but as objects that can be exploited. 
The problem of outsourcing in Indonesia is in line with the large number of outsourced workers, especially in the City of Ternate where the rights of workers/laborers are often neglected by outsourcing service companies, therefore it is necessary to increase guidance and supervision by the local government so that the protection of workers' rights can be fulfilled. In the midst of public concern about the dangers of capitalism reborn, the government has legalized the practice of outsourcing which is economically and morally detrimental to workers/laborers. The implementation of outsourcing work refers to the Regulation of the Minister of Manpower and Transmigration of the Republic of Indonesia Number 19 of 2012 concerning Conditions for Submission of Partial Implementation of Supporting Work to Other Companies. The controversy is based on the interests that underlie the concept of thought of each subject. Those who agree argue that outsourcing is beneficial in business development, spurring the growth of new forms of business known as outsourcing service companies which indirectly create job opportunities for job seekers, and even in various countries this practice is beneficial in terms of increasing taxes, growth of the business world, alleviating unemployment and poverty as well as increasing people's purchasing power, while for companies it is certain, because every business policy remains profit-oriented.

From this, the author sees that there are many shortcomings that must be addressed by the government related to regulations governing the form of outsourcing as happened in the City of Ternate where this is a company that submits supporting work to a service provider company workers / laborers often do not follow the required provisions. in the Permenakertras of the Republic of Indonesia Number 19 of 2012 which types of work can be submitted and the types of work that cannot be submitted to workers/labor service providers. Then in the implementation of the delivery of part of the supporting work, sometimes the company never reports the type of supporting work submitted from the company providing the job to the company accepting the job as well as the contracting agreement between the company providing the job and the company receiving the job and the work agreement between the service provider company and the worker/employee. workers who have never been registered with the local Manpower Office, this makes the company unable to be properly controlled by the government related to the rights of workers/laborers whose rights are often neglected and never noticed by outsourcing service companies.

Based on the provisions that have been regulated regarding its implementation, there are jobs that are carried out by the company themselves and there are also jobs that are submitted/transferred to other companies. The process of transferring a job and service that was previously performed by a company to a third party is called outsourcing. The concept of outsourcing is the delegation of daily operations and management of a business process to an outside party (outsourcing service provider company). Through delegation, the management is no longer carried out by the company providing the work, but is delegated to the outsourcing service company.

The working relationship that occurs in this outsourcing practice is different from the work relationship in general, because in outsourcing there is a triangular working relationship, it is said to be triangular because there are 3 (three) parties involved in the outsourcing work relationship, namely the company providing the job, and the company party. worker/labor service provider or job contracting company, namely the company that accepts the job and lastly is the worker/labourer party. Because it is triangular in nature, the working relationship that exists between the three is a work relationship between the company providing the job and the company receiving the job, namely the service provider company, and the working relationship between the service provider and the worker/ laborer.

The company providing the job is only bound to fulfill its obligations to the company accepting the job and vice versa, so under normal circumstances the company providing the job is not responsible for fulfilling the rights of workers/laborers unless there is a violation of the terms and conditions of outsourcing. The one who is directly responsible for fulfilling the interests and rights of the worker/labor is the service provider company (the company that accepts the job), because of the relationship between the worker/labourer's employment agreement and the company receiving the job in accordance with Article 1 Paragraph (1) (2) (3) (4) and (5) Permenakertrans of the Republic of Indonesia Number 19 of 2012. 
Outsourcing Employment Relationship Structure Chart:

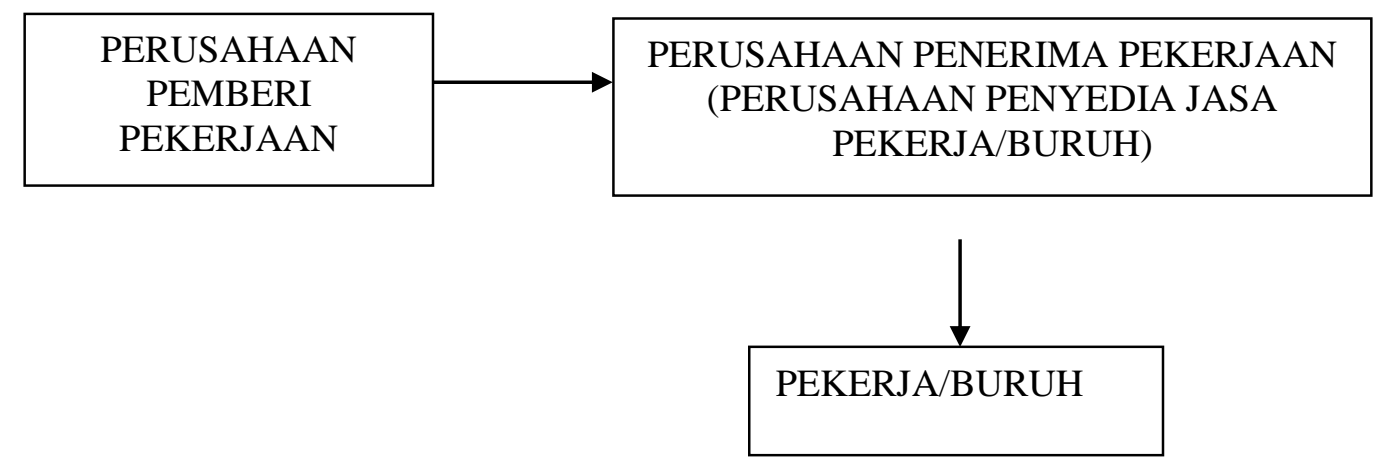

According to Hari Supriyanto "labor law which has prominent public elements will cause the labor law to contain provisions that are coercive". ${ }^{1}$ Due to its coercive nature, labor laws must be monitored and enforced in order to provide protection and a sense of justice for workers/laborers as well as employers and the community. "Law enforcement at this time is given a broader meaning, not only regarding the implementation of the law (law enforcement), but also includes preventive measures, in the sense of making laws. $^{2}$

Law enforcement is intended to achieve a legal goal, namely tranquility and peace in social relationships and relationships.

"Law enforcement aims to create peace in the association of human life. Peace in social life on the one hand means the existence of order (which is external between personal or interpersonal), and on the other hand means peace (which is interpersonal or personal). Both must be in harmony, then peace can be achieved". 3

Manpower law enforcement is carried out by Labor Inspection Employees as state apparatus responsible for supervising the application of labor law, this is stated in Article 176 of the Law of the Republic of Indonesia Number 13 of 2003 concerning Manpower which states:

"Manpower inspection is carried out by competent and independent labor inspectors to ensure the implementation of labor laws and regulations"

As for the purpose of holding labor inspection as stated in Article 1 of the Law of the Republic of Indonesia Number 3 of 1951 concerning the Declaration of the Enforcement of the Law of Labor Supervision of 1943 Number 23 of the Republic of Indonesia for the whole of Indonesia:

1. monitor the enforcement of labor laws and regulations in particular;

2. collect information materials on issues of employment relations and labor conditions in the broadest sense in order to make labor laws and regulations,

3. carry out other work assigned to him by other laws or regulations. ${ }^{4}$

The law enforcement process is a series of activities in order to realize abstract ideas or concepts into reality, "Efforts to realize ideas or values always involve the environment and the influence of other factors". Therefore, if you want to enforce the law, then the law must be seen as a unified system.

\footnotetext{
${ }^{1}$ Nyoman Serikat Putra Jaya, Some Thoughts towards the Development of Criminal Law, PT. Citra Aditya Bakti, Bandung 2008, p. 133.

${ }^{2}$ Soerjono Soekanto, Penegakan Hukum, Bina Cipta Bandung, 1983, hal 15

${ }^{3}$ Hari Supriyanto, Op Cit, page 44

${ }^{4}$ Djoko Triyanto, Employment Relations in a Construction Service Company, Mandar Maju, Bandung, 2004, p. 159.
} 
According to Lawrence M. Friedman as quoted by Esmi Warassih, "the law is a combination of the components of structure, substance and culture". By Friedman, legal structure is likened to a machine, substance is what is produced or done by machines, and legal culture is who decides to turn on or turn off the machine. Only one supporting component does not work, the system will experience a dysfunction (limp). ${ }^{5}$ From the facts that occurred regarding the legal protection of outsourced workers/laborers in the City of Ternate and of the many outsourcing service companies, one of which is the object of the author's research is PT. Paguntaka Cahaya Nusantara and Outsourcing Service company PT. Prima Karya Sarana Sejahtera (PKSS) in Ternate.

Of the two types of activities known as outsourcing in the Regulation of the Minister of Manpower of the Republic of Indonesia Number 19 of 2012 concerning the Conditions for Submission of Partial Work Implementation to Other Companies. As has been amended by the Regulation of the Minister of Manpower of the Republic of Indonesia Number 27 of 2014 concerning Amendments to the Regulation of the Minister of Manpower and Transmigration Number 19 of 2012. The amendment is only an addition to the paragraph, namely Article 1 number 5a. and article 25 point 5A. namely with the following sound: Between Article 1 number 5 and number 61 (one) number is inserted, namely number 5a so that it reads as follows: Article 1 5a. Foreign investors are individual foreign citizens, foreign business entities, and/or foreign governments that make investments in the territory of the Republic of Indonesia. Between Article 25 and Article 26, 1 (one) Article is inserted, namely Article 25A so that it reads as follows: Article 25A. In the event that the service provider company for workers/labor is a foreign investor, the operational permit as referred to in Article 25 is issued by the Investment Coordinating Board.

The latest regulation issued by the government is Law Number 11 of 2020 concerning Job Creation in conjunction with Government Regulation Number 53 of 2021 concerning Work Agreements for Certain Time, Outsourcing, Working Time and Rest Time, this research only uncovers the complexity of the implementation of handing over part of the work to the company. other (charter work) as regulated in the Regulation of the Minister of Manpower and Transmigration of the Republic of Indonesia Number 19 of 2012 concerning Conditions for Submission of Partial Work Implementation to Other Companies. Because in the practice of chartering this work there are many deviations or violations of the terms and conditions of outsourcing as well as legal protection of the rights of outsourced workers/laborers, but in this study the author focuses more on legal protection of the rights of workers/laborers consisting of relationship status work rights, eligible wages, normal working hours, BPJS Employment and Health BPJS rights, overtime pay rights, maternity leave rights, annual leave rights and religious leave rights, as well as the rights of other workers/laborers as regulated in Law No. 13 of 2003 concerning Manpower.

The author believes that, the results of this research will be useful for public policy makers to review or even reform the existing labor law system and can make better regulations in order to protect the rights of outsourced workers/laborers and must be closely monitored by the government. , because the inequalities in the components of substance, structure and culture have a fairly broad impact on the community, especially the workers/labor community and the business world as well as efforts to enforce the labor law itself. ${ }^{6}$

Based on the description above, the author is interested in analyzing in depth, the problem research is what is the Form of Protection of Legal Rights and Obligations Against Workers/Labourers at Outsourcing Service Companies in Ternate City?.

\section{Research Methods}

The type of research used is normative legal research that examines the factual implementation or implementation of certain legal events. The study aims to ascertain whether the results of the implementation are in accordance with the provisions of the legislation. There are 2 (two) stages of this

\footnotetext{
${ }^{5}$ Natabaya, Indonesian Legislation System, Secretary General and Registrar of the Constitutional Court. RI. 2006.

${ }^{6}$ Then Husni 2003 introduction to labor law. Jakarta ;Rajawali Press Page 33-34
} 
normative and empirical legal research. Phase I is a study of normative law, namely the book of laws and regulations. Phase II is a study of empirical law in the form of the implementation of these legal events. So this research requires secondary data and primary data. ${ }^{7}$

\section{Results and Discussion}

\section{Legal Protection for Workers/Labourers at Outsourcing Service Companies in Ternate City}

The rights of workers in Law Number 13 of 2003 concerning Manpower are as follows:

1. Every worker has equal opportunity without discrimination to get a job (Article 5);

2. Every worker/labor has the right to receive equal treatment without discrimination from employers (Article 6);

3. Every workforce has the right to obtain and/or improve and/or develop work competencies in accordance with their talents, interests and abilities through job training (Article 11);

4. Every worker/ laborer has the same opportunity to participate in job training in accordance with his/her field of duty (Article 12 paragraph (3);

5. Workers have the right to obtain recognition of work competence after participating in job training organized by government job training institutions, private job training institutions or training in the workplace (Article 18 paragraph (1);

6. Workers who have participated in the apprenticeship program are entitled to recognition of work competency qualifications from companies or certification bodies (Article 23);

7. Every worker/labor has the right to obtain protection for:

a. Job safety;

b. morals and decency; and

c. Social and health protection via social security (BPJS Health as referred to in Article 5 paragraph (2) letter a shall administer a health insurance program and BPJS Ketenagakerjaan as referred to in Article 5 paragraph (2) letter b organizes the following programs):

\section{Construction of Work Norms}

The public policy of the Ternate City Government in the field of employment in the legal protection of workers/laborers as a whole, especially against outsourced workers/laborers. This can be seen from the poor condition of workers/laborers from a political, economic, cultural and legal point of view. From a political perspective, the position of outsourced workers/laborers is still marginalized when dealing with employers and the government in the decision-making process for resolving industrial relations disputes regarding the fulfillment of their basic rights. This includes the right to strike, the right to organize, assemble and express opinions, as well as the right to bargain collectively. From an economic point of view, workers/labourers still get low wages, long and erratic working hours, poor social security and health, arbitrary layoffs, discrimination, and unclear working relationships which have an impact on the unclear future of workers/labor with his family. ${ }^{8}$

\section{Development of OSH Norms}

Guidance in the context of implementing occupational safety and health norms in outsourcing practices in the City of Ternate as ordered by Article 5 Article 6 Article 7 Per. 08/Men/VII/2010. regarding Personal Protective Equipment (PPE), for Workers/laborers and other people who enter the workplace are required to wear or use PPE in accordance with the potential hazards and risks. Furthermore, based on article 14 letter c of Law no. 1 of 1970, concerning Occupational Safety, "Managers are required to provide PPE for workers under their leadership and other people who enter the workplace". in the application of Occupational Safety and Health K3 in the company personal protective equipment (PPE) is adjusted to the workplace that requires it so as to minimize the risk of work accidents that occur in the workplace. Adequate

\footnotetext{
${ }^{7}$ Satjipto Raharjo, Legal Studies, Bandung : PT. Image of Aditya Bakti, 2000, p. 53

${ }^{8}$ Lili Rasjidi and I.B Wysa Putra, Law as a System, (Bandung: Rusdakarya Youth, 1993) g. 118
} 
personal protective equipment to maintain safety and health. Because in addition to the risk of occupational accidents, there is also a risk of occupational diseases due to the use of chemicals for fertilizers and toxins. Every worker/labor, including outsourced workers/laborers, is always faced with the potential danger of accidents and Occupational Diseases (PAK) according to the type or characteristics of the company where they work. Where work accidents and occupational diseases will have a very detrimental impact on workers/laborers, companies and the community. The law has required that employers always control losses from accidents (control of accident loss), as well as identify and eliminate (control) unacceptable risks (the ability to identify and eliminate unacceptable risks) in the work environment, so that safety is guaranteed. and occupational health (K3). The application of $\mathrm{K} 3$ norms applies to the entire work environment, including the outsourcing work environment.

\section{Conclusion}

Legal Protection Against Workers/Labourers in Outsourcing Service Companies:

a. Whereas in the practice of outsourcing, the company providing PT. PLN (Persero) Maluku Development Parent Unit and the company accepting the job is an outsourcing service company PT. Paguntaka Cahaya Nusantara before carrying out the work, it is obligatory to record and ratify the work chartering agreement to the local manpower agency.

b. That the outsourcing service company PT. Paguntaka Cahaya Nusantara is required to make a work agreement with the worker/labor after it is signed by both parties, it can be registered at the local Manpower Office. For wage requirements, the company can provide wages according to the 2021 UMK

c. Outsourcing service company PT. PKSS which has employed security unit workers/laborers at the company that employs PT. Cakrawala Samudra Biru with a working time of 12 working hours per day there is an excess of 4 hours of normal working hours, as overtime hours for the company to be able to improve working time according to normal working hours, namely 8 hours of work per day or 7 hours of work per day and annual leave must be granted to workers/laborers for 12 working days in accordance with applicable regulations.

d. The company's obligations to fulfill the rights of workers/laborers consist of wages for workers/laborers in accordance with the UMK of Ternate City in 2021, regulating normal working hours, paying overtime wages, and providing leave to outsourced workers/laborers in the City of Ternate in accordance with the laws and regulations -applicable invitation.

\section{Legal Consequences for Companies Not Fulfilling Obligations.}

Employer company PT. PLN (Persero) UIP Maluku which handed over supporting work to outsourcing service company PT. Paguntaka Cahaya Nusantara by not reporting the types of supporting work to the local Manpower Office for recording and ratification. Therefore, the legal status of the outsourced worker/laborer has switched to a working relationship with the employer company in accordance with the Minister of Manpower and Transmigration Regulation Number 19 of 2012 and has been given a coaching warning letter.

a. Outsourcing service company PT. PKSS provides workers/laborers with the right to annual leave of only 3 (three) days based on the applicable provisions, the right to annual leave must be granted for 12 (twelve) working days.

b. Outsourcing service company PT. PKSS does not carry out the working hours of the security guard in accordance with normal working hours, namely 7 working hours per day and 40 working hours per week for 6 (six) working days, 1 (one) day off, and 8 (eight) working hours per week. days and 40 (forty) working hours per week for 5 (five) working days there are 2 (two) days off. For outsourced workers/laborers employed in the company that employs PT. Cakrawala Samudra Biru, there are 4 (four) hours of overtime for the company to improve its working hours for the violation, the company has been given a coaching warning letter by the local Manpower Office. 
c. A letter of reprimand for these violations if the company does not make improvements, an investigation and legal action can be carried out, namely justitia's repressive action.

2. The Role of the Government Through the Manpower Office in Providing Legal Protection

a. The role of the government through the local Manpower Office is to add personnel to the labor inspectorate to maximize the guidance and supervision of companies in the City of Ternate, especially outsourcing service companies so that the rights of workers/laborers are fulfilled in accordance with applicable regulations.

b. Guidance and supervision carried out by the government through the Manpower Office must be more active so that the application of labor regulations can be carried out in companies in accordance with government programs for the sake of improving work norms and OSH norms in companies in accordance with applicable regulations.

\section{Bibliography}

\section{Book}

Esmi and Natabaya, 2006, Indonesian Legislation System, Secretary General and Registrar of the Constitutional Court. RI.

Harjono and Marmi Emmy Mustafa, 2007, Principles of Law Enforcement in Patent Law Enforcement in Indonesia Tied to TRiPs-WTO, PT. Alumni, Bandung.

Husni Lalu, 2003, Introduction to Labor Law. Rajawali Press, Jakarta.

Jaya, Nyoman Serikat Putra, 2008, Some Thoughts towards the Development of Criminal Law, PT. Citra Aditya Bakti, Bandung.

Khakim Abdul, Introduction to Indonesian Manpower Law, Based on Law Number 13 Year 2003, PT. Image of Aditya Bakti. Bandung.

Koentjoro, Diana Halim, 2004, State Administrative Law, Ghalia Indonesia, South Bogor.

Lili Rasjidi and I.B Wysa Putra, 1993, Law as a System, Rusdakarya Youth, Bandung.

Satjipto Raharjo, 2000, Legal Studies, Bandung: PT. Image of Aditya Bakti.

Soekanto Soerjono, 1983, Law Enforcement, Bina Cipta, Bandung.

1983, Some Legal Issues in the Framework of Development in Indonesia. Publisher: UI-Press.

Soeroso and Chainur Arrasjid, 2005, Fundamentals of Legal Studies, Publisher: Sinar Graphic.

Soetami A.Siti, 2000, State Administrative Law, Publishing Agency Diponegoro University, Semarang.

Syafa'at Rachmad. 2008, Labor Movement and Fulfillment of Basic Rights, Labor Strategy in Conducting Advocacy. Publisher: In-TRANS Publication, Malang.

Triyanto Djoko, 2004, Employment Relations in a Construction Service Company, Mandar Maju, Bandung.

Ernst Utrecht 1962, Introduction to State Administrative Law, Pustaka Tinta Mas, Surabaya. 
Victor M. Situmorang and Jusuf Juhir, 1994, Legal Aspects of Inherent Supervision in the Government Apparatus, PT. Rineka Cipta, Jakarta.

\section{Laws and Regulations}

Law of the Republic of Indonesia Number 3 of 1951 concerning Labor Supervision.

Law of the Republic of Indonesia Number 1 of 1970 concerning Occupational Safety and Health (K3).

Law of the Republic of Indonesia Number 13 of 2003 concerning Manpower.

Law of the Republic of Indonesia Number 21 of 2003 concerning Ratification of the ILO Convention No. 81 Concerning Labor Inspection in Industry and Commerce (ILO Convention No. 81 concerning Labor Inspection in Industry and Trade).

Law of the Republic of Indonesia Number 24 of 2011 concerning BPJS.

Law of the Republic of Indonesia Number 11 of 2021 concerning Job Creation.

Decree of the Minister of Manpower and Transmigration of the Republic of Indonesia Number 100/Men/VI/2004 concerning Certain Time Work Agreements (PKWT).

Decree of the Minister of Manpower and Transmigration of the Republic of Indonesia Number 102/Men/VI/2004 concerning Overtime Working Time and Overtime Wages.

Regulation of the Minister of Manpower and Transmigration of the Republic of Indonesia Number 19 of 2012 concerning Conditions for submitting some work to other companies.

Government Regulation of the Republic of Indonesia Number 35 of 2021 concerning Certain Time Work Agreements, Outsourcing of Working Time and Rest Time, and Termination of Employment.

Government Regulation of the Republic of Indonesia Number 36 of 2021 concerning Wages

\section{Website}

Source: journal.uin-alauddin.ac.id written by Muhammad Rusydi Rasyid in 2015.

\section{Copyrights}

Copyright for this article is retained by the author(s), with first publication rights granted to the journal.

This is an open-access article distributed under the terms and conditions of the Creative Commons Attribution license (http://creativecommons.org/licenses/by/4.0/). 